\title{
DEVELOPMENT OF MANUFACTURING INVENTORY MANAGEMENT SYSTEM USING MATERIAL REQUIREMENT PLANNING METHOD
}

\author{
Ami Rahmawati $\left.{ }^{*}\right)$, Rizal Amegia Saputra², Ita Yulianti ${ }^{3}$ \\ Sistem Informasi \\ Universitas Nusa Mandiri \\ ami.amv@nusamandiri.ac.id ${ }^{1 *}$
Sistem Informasi Akuntansi Kampus Kota Sukabumi
Universita Bina Sarana Informatika
rizal.rga@bsi.ac.id², ita.iyi@bsi.ac.id³

(*) Corresponding Author

\begin{abstract}
Abstrak
Inventori memiliki peranan penting dalam aktivitas bisnis. Hal ini dikarenakan inventori berpengaruh terhadap perubahan pasar produksi serta mengantisipasi perubahan harga dalam permintaan barang yang banyak. PT. Barkah Jaya Mandiri merupakan perusahaan yang bergerak dalam bidang manufaktur dimana pengelolaan inventory barang pada perusahaan tersebut masih dilakukan secara konvensional. Hal tersebut menyebabkan timbulnya berbagai masalah seperti terjadinya selisih pada stok barang, ketidaksesuaian data dan laporan akhir serta kendala pada proses produksi apabila terjadi kekurangan maupun kelebihan bahan baku.Oleh karena itu, melalui penelitian ini akan dibuatkan sistem berbasis desktop menggunakan bahasa pemrograman JAVA dengan metode MRP (Material Requirement Planning) agar dapat mengatasi permasalahan yang terjadi pada perusahaan tersebut. Penggabungan antara model SDLC dan teknik pengumpulan data meliputi observasi, interview dan studi pustaka juga dilakukan pada penelitian ini guna tercapainya sistem yang akan dibangun agar sesuai dengan kebutuhan yang ditargetkan. Dengan adanya sistem tersebut, pengelolaan data inventory pada perusahaan ini dapat dilakukan dengan mudah dan akurat serta mengefektifkan waktu dibandingkan dengan sistem berjalan sebelumnya, sehingga aktivitas pengadaan bahan baku manufaktur menjadi optimal dan kinerja karyawanpun menjadi lebih baik.
\end{abstract}

Kata kunci: Inventori, Pemrogramman Java, Material Requirement Planning, SDLC

\begin{abstract}
Inventory has an important role in business activities. This is because inventory has an effect on changes in the production market and anticipates price changes in the demand for many goods. PT. Barkah Jaya Mandiri is a company engaged in manufacturing where the management of inventory at the company is still done conventionally. This causes various problems such as the occurrence of discrepancies in the stock of goods, discrepancies in data and final reports as well as obstacles in the production process in the event of a shortage or excess of raw materials. (Material Requirement Planning) in order to overcome the problems that occur in the company. The combination of the SDLC model and data collection techniques including observation, interviews and literature study were also carried out in this study in order to achieve the system that will be built to suit the targeted needs. With this system, the management of inventory data at this company can be done easily and accurately and save time compared to the previous system, so that the procurement of manufacturing raw materials is optimal and employee performance is better.
\end{abstract}

Keywords: Inventory, Java Programing, Material Requirement Planning, SDLC

\section{INTRODUCTION}

Inventory can be interpreted as items stored for use or sale in the future or period (Prasetya \& Prakoso, 2020). Inventory has an important role in business activities (Nur Fazli \&
Jumaryadi, 2019). This is because inventory affects changes in the production market and anticipates price changes in demand for large quantities of goods (Mufida et al., 2019).

Inventory management information system is a system to collect and maintain data that 
explains the inventory of goods and converts the data into information and report to users (Indrian \& Sudarmadi, 2015). Activities on inventory management in general consist of the data collection of overall inventory, expenditure, procurement and transfer of goods and so on (Rahmadi \& Yusmiarti, 2016).

The tighter business competition in the business world, speed and accuracy in acting is a major thing (Pahlevi et al., 2018). Strategies in data processing and supporting facilities are needed to help process data quickly and produce the necessary reports of the company (Hasan, 2017). By utilizing the development of existing information technology, data processing is done easily and produce information that is needed accurately and effectively time, as well as costs incurred more efficiently (Hengki \& Suprawiro, 2017).

PT. Barkah Jaya Mandiri is one of the companies in Sukabumi Regency engaged in manufacturing. Inventory management of goods in this company is still done conventionally, especially on the recording of in and out of goods, demand for procurement of raw materials and reports of purchases and use in the quantity of items still using the receipt book. This causes various problems such as differences in the stock of goods, data discrepancies and final reports between warehouse heads and warehouse admins even when the data search takes a relatively long time (Bustami, 2021). In addition, the planning of procurement of raw materials is still carried out based on estimates only, so it is not surprising if there is a shortage or excess of raw materials that can slow down the production process which leads to incorrect target delivery time to customers if there is a shortage of raw materials, and vice versa if excess will impact the high cost of storage and the risk of loss and damage to raw materials (Pratama \& Latipah, 2019).

Based on these problems, it is proposed the creation of an application system for inventory management of goods as an alternative solution to the current problems. There are several similar studies that have previously implemented such systems as inventory information systems at Riau University Hospitals (Nasution \& Frianti, 2019), CV. Limoplast (Nurlaela et al., 2019) and UD. Berkah Jaya (Ariani \& Taufik, 2021). The three studies both utilize php programming language to build a webbased inventory information system in managing inventory or stock of goods so as to facilitate employees in making reports. But in this study, the system will be created desktop-based using JAVA programming language to provide newness compared to previous research. On the other hand, the application of MRP (Material Requirement
Planning) method is also widely used in various research related to inventory because it is considered capable of controlling the amount of raw materials that must be prepared or purchased according to production needs (Susmita \& Cahyana, 2018)(Rishmaya, 2020). Therefore, to provide novelty compared to previous research, the system will be built by implementing the MRP method into desktop-based programs using the JAVA programming language to support the management of production processes, especially in controlling the supply of raw materials at PT. Barkah Jaya Mandiri.

The purpose of this research is to improve the weaknesses in the existing system by building a program that can cover the need to manage raw material inventory in PT. Barkah Jaya Mandiri. With the system is expected to provide convenience and benefits for the company in optimizing procurement activities ranging from the management of raw material data, scheduling purchases, and making reports.

\section{RESEARCH METHODS}

The data used as a means of supporting the achievement of this research was obtained by observation, interview and literature review.

1. Observation

This observation was carried out at PT. Barkah Jaya Mandiri with the aim of being able to produce a better picture of the research that will be made.

2. Interview

This data collection technique is done by interacting and conducting questions and answers regarding the inventory management system to the warehouse admin at PT. Barkah Jaya Mandiri.

3. Literature Review

Literature study was carried out by looking for various references including books and e-books related to making applications and supporting articles obtained from the internet.

\section{Types of research}

This type of research is in the form of qualitative research. This research is a research that emphasizes on understanding the problems in social life based on the conditions of reality, a holistic, complex and detailed natural setting (Anggito \& Setiawan, 2018). Therefore, a case study approach was carried out to achieve the objectives of this study supported by the main data collection techniques including observation, interviews and literature study. 


\section{Time and Place of Research}

This research was conducted in January 2021 at PT. Barkah Jaya Mandiri which is located in the Sukabumi Industrial Center Complex (SENTRIS) Block D4 Cipancur, Cisaat Kab. Sukabumi West Java Province.

\section{Research Target / Subject}

This study aims to update the system that is currently running at PT. Barkah Jaya Mandiri by utilizing computer technology and building a desktop program in the inventory management system as a solution in dealing with problems that occur so as to improve and optimize employee performance. This was chosen for the reason that the development of computer technology today has very important and useful contributions in various fields of life, ranging from education, economics, geography, health, and others (Prasanti \& Indirani, 2018).

\section{Procedure}

The design of the program in this study was carried out using the waterfall model. This method is sometimes called a linear sequential model or classical life flow model which provides a sequential or sequential software lifeflow approach starting from requirements analysis, design, coding, testing and support stages (S. \& Shalahudin, 2018).

\section{Data, Instruments, and Data Collection Techniques}

In addition to data collection techniques, sdlc model is also implemented as a method of software development in creating programs that will be built in this research.

1. Need Analysis

This stage begins with an analysis of the specifications of the system requirements to be built such as goods data, incoming goods data, outgoing goods data and others, which will later be involved in making inventory management applications.

2. Design

Design representation implemented in the form of ERD and UML with the aim of describing the design of the system to be built so that the applications created can run optimally.

3. Coding
At this stage, the results of the design are translated into software programs with the JAVA Programming Language in Netbeans applications. In addition, the MRP method is also added in the program built in order to provide predictions of raw materials that must be prepared on the next production scheduling. Material requirements planning (MRP) is a scheduling method for purchased plans and manufactured planned orders submitted for further analysis with regard to capacity availability (Susmita \& Cahyana, 2018). The output generated from the MRP method is information that can be used to carry out production control in the form of orders arranged based on the timing of each component/item (Pratama \& Latipah, 2019).

4. Testing

Testing is done by testcomplete to know if the application used can run as needed. TestComplete is an automated testing tool used for functional testing and automated scripts can be composed from Python, C++Script, VBScript, Jscript, or JavaScript languages as well. It supports different testing types and methods, for example; functional testing, unit testing, and GUI testing (Okezie et al., 2019). TestComplete has evaluated to test program in context to factors i.e. load performance, response time etc. with respect to the number of users or threads (Lenka et al., 2018).

5. Maintenance

The maintenance phase can repeat the development process ranging from specification analysis to existing software changes, but not to creating new software.

\section{RESULTS AND DISCUSSION}

\section{System Requirements Analysis}

The stages of system requirements analysis in this study are described with the help of ERD and UML.

\section{a. Entity Relationship Diagram}

The following is a display of the ERD designed for system development in this research: 


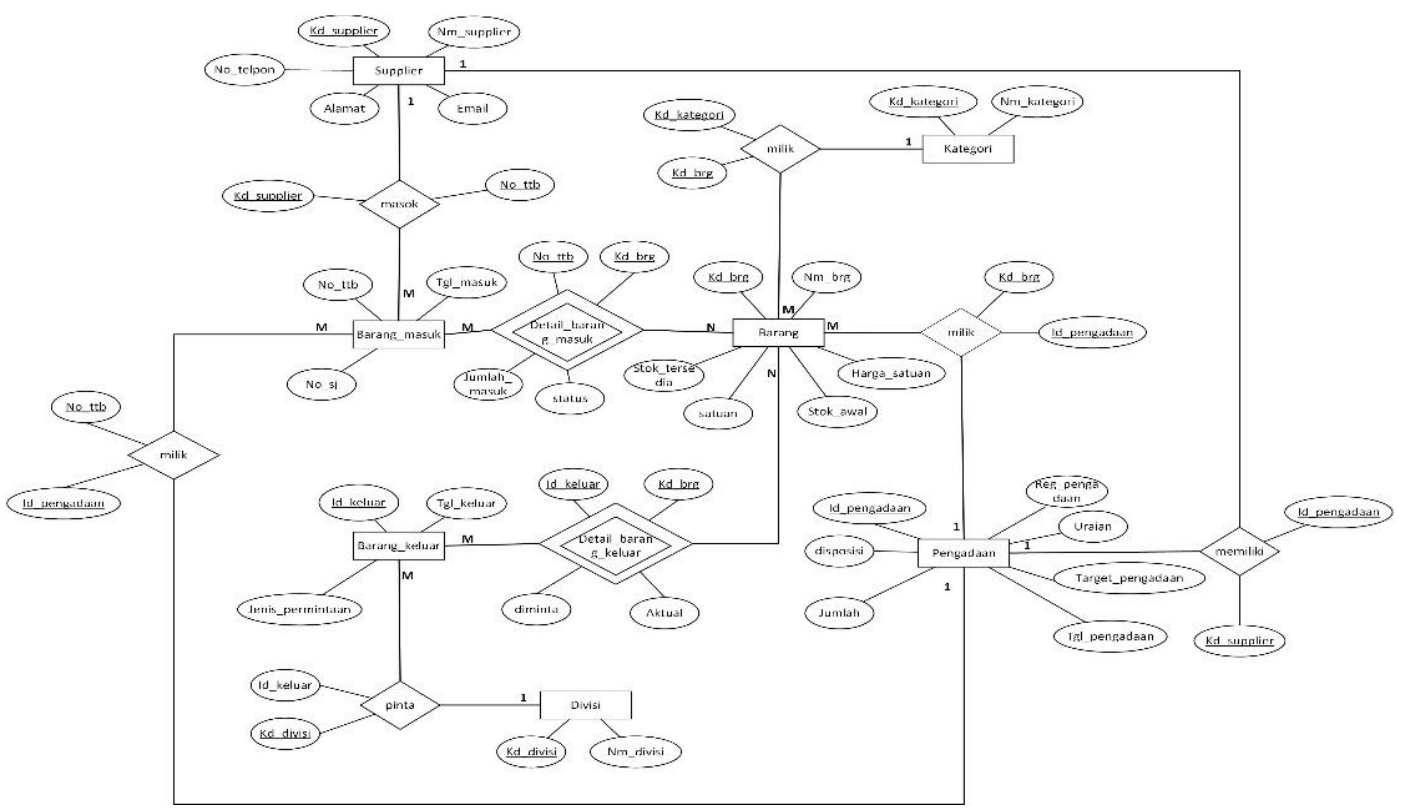

Figure 1. Entity Relationship Diagram apa??

Based on the erd, databases and tables that have been designed are then created using MySQL.

\section{b. Use Case Diagram}

There are two use case diagrams designed in this study, namely for Warehouse Admin and Warehouse Head. The following is a display of the Warehouse Admin use case:

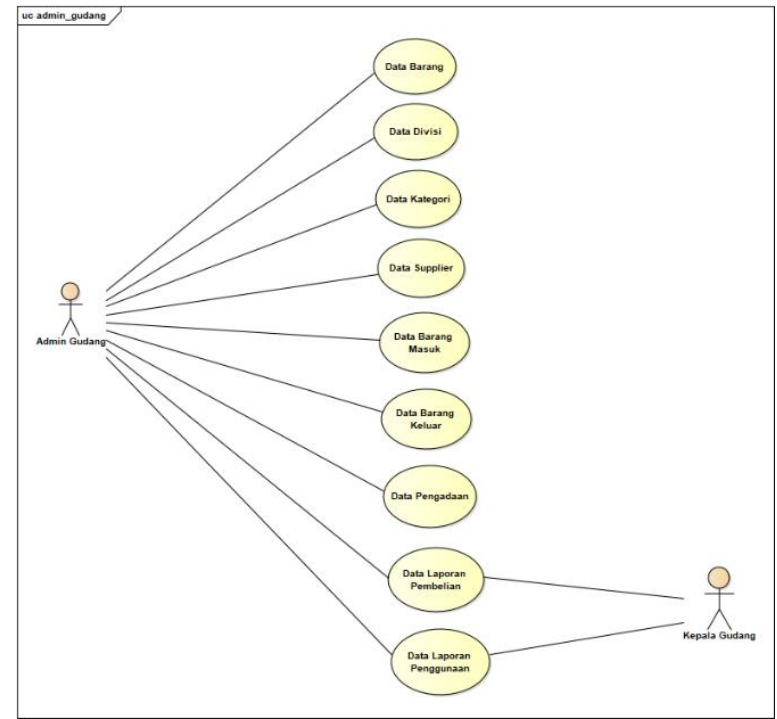

Figure 2. Warehouse Admin Use Case Diagram

If the Warehouse Admin will manage goods data, division data, category data, supplier data, incoming goods data, outgoing goods data, procurement data, purchase report data, and goods usage report data, they must first log in. After logging in, the warehouse admin can enter the main menu.
A warehouse head can only manage purchase report data and goods usage report data. To manage the data, the head of the warehouse is required to login first to the system.

\section{c. Activity Diagram}

The following is a figure of the Activity Diagram made in this study:

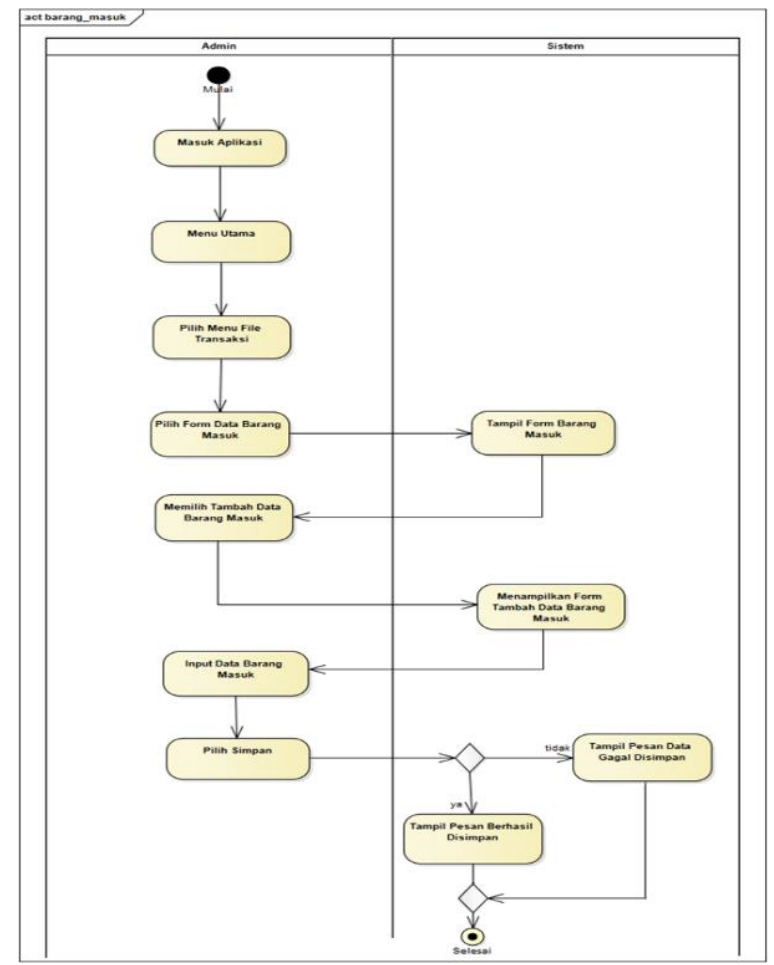

Figure 4. Activity Diagram 
JURNAL RISET INFORMATIKA

Vol. 4, No. 1 December 2021
P-ISSN: 2656-1743 |E-ISSN: 2656-1735

DOI: https://doi.org/10.34288/jri.v4i1.271
From the diagram (see Figure 4.), it can be seen that the design of the proposed system is based on the system's previous procedures.

\section{d. Class Diagram}

In addition to use cases and activity diagrams, class diagrams were also made in this study which are presented in the following figure:

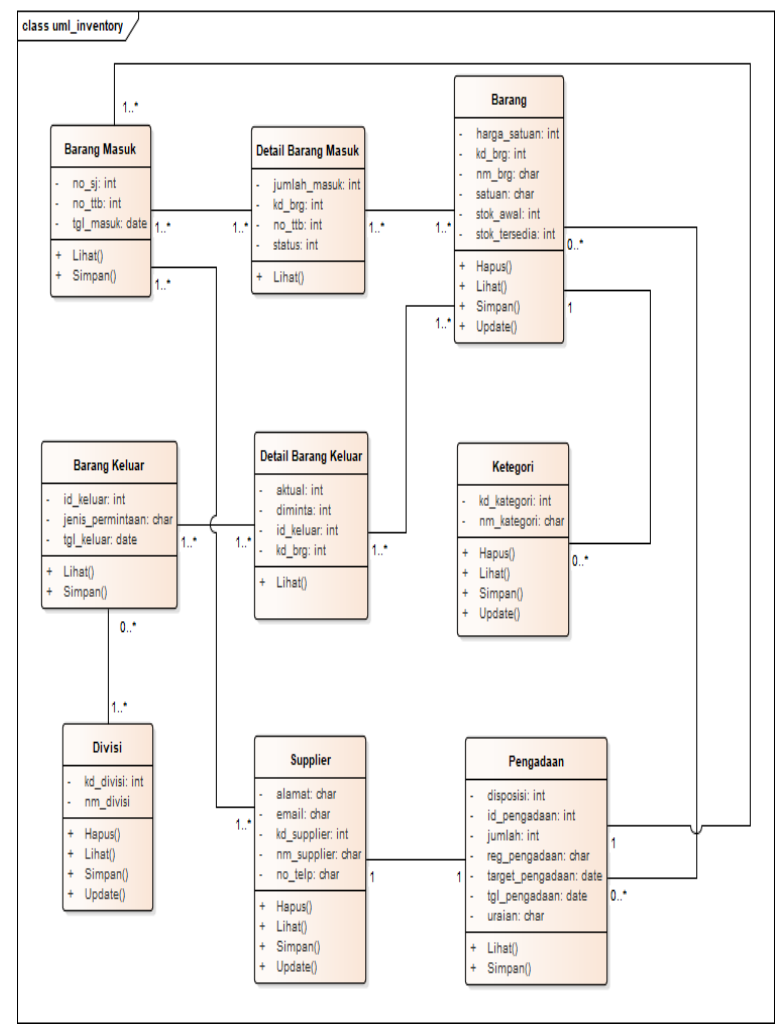

Figure 5. Class Diagram

The diagram shows the design of the system structure/scheme that describes the classes, attributes, methods, and relations of each object.

1. Implementation

a. Login Page

The initial view on the built system is a login page that can be seen in the following figure:

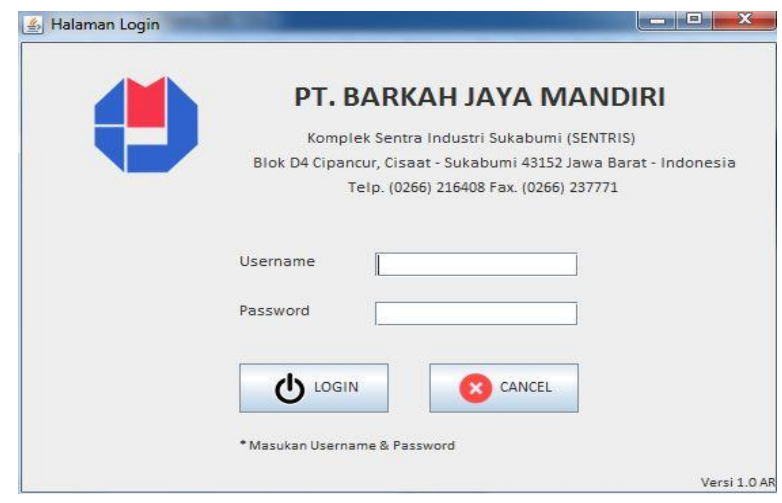

Figure 6. Login Page
In this inventory program, if you log in as a warehouse admin, you can access all parts of the program that have been created such as item data, category data, division data, supplier data, incoming goods data, outgoing goods data, procurement of goods and reports. But, if you are logged in as the head of the warehouse, you cannot access all existing data, you can only access report data.

\section{b. Main Menu Page}

Furthermore, if the login is successful, the master menu will appear as shown in Figure 7.

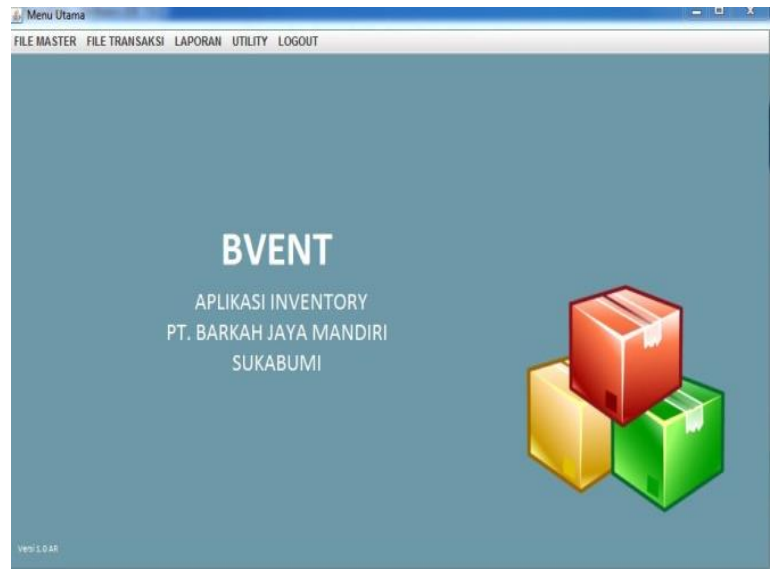

Figure 7. Main Menu Page

On the main menu page, various menus from the inventory application will appear that can be accessed by the warehouse admin and warehouse head.

c. Item Data Form Page

Figure 8. shows a item data form page. In this form, warehouse admin can processing data including input, edit and delete inventory items contained in PT. Barkah Jaya Mandiri.

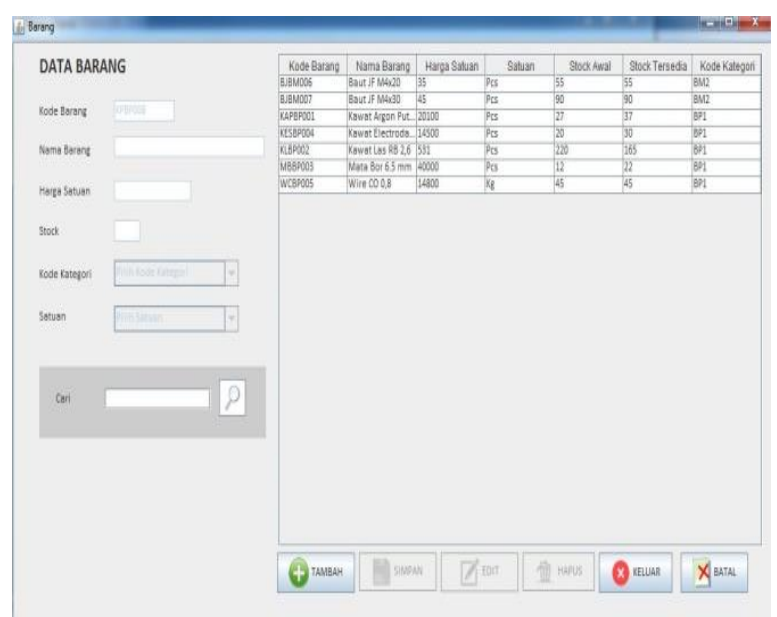

Figure 8. Item Data Form Page 
d. Incoming Goods Data Form Page

Figure 9. shows a incoming goods data form page. This form can processing incoming goods data, such as the first item arrives, the item is inputted by the warehouse admin.

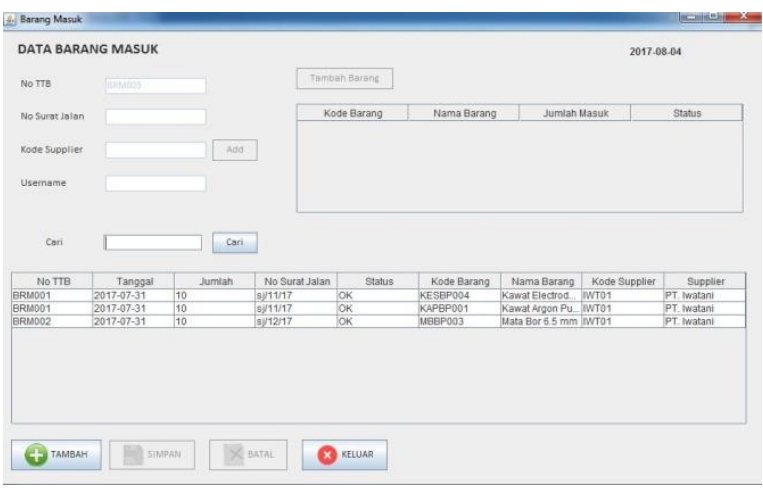

Figure 9. Incoming Goods Data Form Page

e. Report Page

Figure 10. shows a report page on the purchase of goods reported to the management. This report can be accessed on the system by warehouse admin and warehouse head.

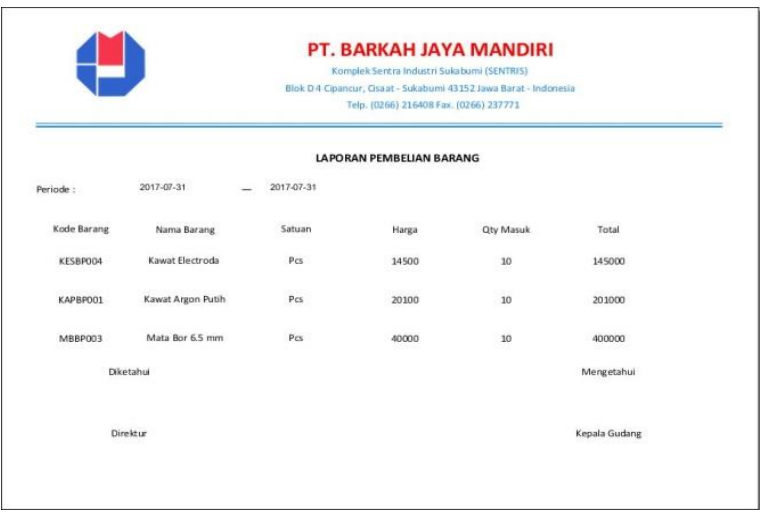

Figure 10. Report Page

\section{f. Planning Form Page}

The following is a display of the planning form page created using MRP method:

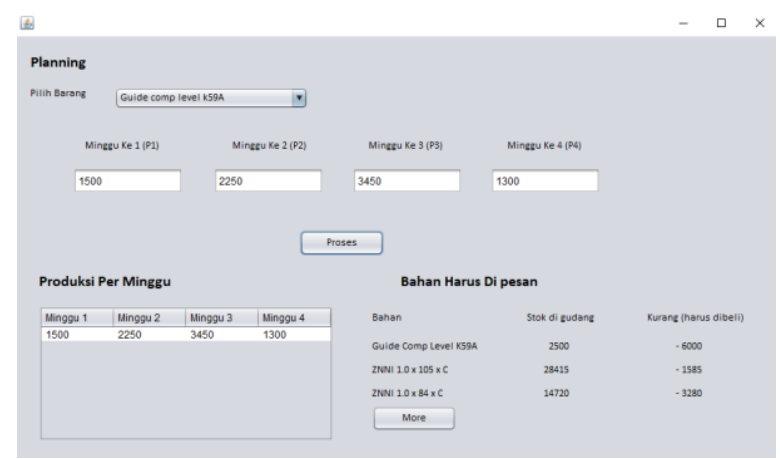

Figure 11. Planning Form Page
In this form, the MRP method is applied by dividing the time of product manufacture into 4 periods so that information can be obtained regarding the inventory of raw materials that are available and which must be purchased according to production needs.

\section{CONCLUSIONS AND SUGGESTIONS}

\section{Conclusion}

By making an inventory management application in general, it can help simplify and optimize the performance of inventory management activities at PT. Barkah Jaya Mandiri. The application of the MRP method in the system is also capable of producing information and scheduling the availability of raw materials needed in the production process.

\section{Suggestion}

Added security for applications made to avoid unwanted things such as human error. Then make automatic data backups such as to the cloud to keep the data safe.

\section{REFERENCES}

Anggito, A., \& Setiawan, J. (2018). Metodologi Penelitian Kualitatif (E. D. Lestari (ed.)). CV. Jejak.

Ariani, F., \& Taufik, A. (2021). Sistem Informasi Inventory (SITORY) Berbasis Web Dengan Metode Framwork For The Application System Thinking (FAST ). JATISI Uurnal Teknik Informatika Dan Sistem Informasi), $8(2)$, 859-869. https://doi.org/10.35957/jatisi.v8i2.930

Bustami, A. (2021). Seputar Perusahaan PT. Barkah Jaya Mandiri.

Hasan, H. (2017). Implementasi Sistem Informasi Pengelolaan Inventory Fixed Asset Pada PT. ARK Logistics dan Transport. Jurnal Perspektif, 15(2), 155-163. https://ejournal.bsi.ac.id/ejurnal/index.php/ perspektif/article/view/2044

Hengki, H., \& Suprawiro, S. (2017). Analisis dan Perancangan Sistem Informasi Inventory Sparepart Kapal Berbasis Web: Studi Kasus Asia Group Pangkalpinang. Jurnal Sisfokom (Sistem Informasi Dan Komputer), 6(2), 121129.

http://jurnal.atmaluhur.ac.id/index.php/sisf okom/article/view/258

Indrian, K., \& Sudarmadi, S. (2015). Sistem Informasi Inventory Alat Tulis Kantor (ATK) 
Menggunakan Metode Waterfall. Jurnal Techno Nusa Mandiri, 12(1), 69-76. http://ejournal.nusamandiri.ac.id/index.php /techno/article/view/499

Lenka, R. K., Mamgain, S., Kumar, S., \& Barik, R. K. (2018). Performance Analysis of Automated Testing Tools: JMeter and TestComplete. International Conference on Advances in Computing, Communication Control and Networking (ICACCCN).

Mufida, E., Rahmawati, E., \& Hertiana, H. (2019). Rancang Bangun Sistem Informasi Inventory Pada Salonkecantikan. Jurnal Mantik Penusa, 3(3), 99-102.

Nasution, S., \& Frianti, R. A. (2019). Sistem Informasi Inventori Obat Berbasis Web di Rumah Sakit Universitas Riau. Seminar Nasional Aptikom (Semnastik) 2019, o(0), 402-409.

Nur Fazli, D., \& Jumaryadi, Y. (2019). Edisi 1 Januari. Ensiklopedia of Journal, 1(2), 22-27.

Nurlaela, L., Dharmalau, A., \& Parida, N. T. (2019). Rancangan Sistem Informasi Inventory Barang Berbasis Web Studi Kasus Pada Cv. Limoplast. Journal of Chemical Information and Modeling, 53(9), 1689-1699.

Okezie, F., Odun-Ayo, I., \& Bogle, S. (2019). A Critical Analysis of Software Testing Tools. Journal of Physics: Conference Series, 1378(4). https://doi.org/10.1088/17426596/1378/4/042030

Pahlevi, O., Mulyani, A., \& Khoir, M. (2018). Sistem Informasi Inventori Barang Menggunakan Metode Object Oriented Di Pt. Livaza Teknologi Indonesia Jakarta. Jurnal PROSISKO, $5(1)$.

Prasanti, D., \& Indirani, S. S. (2018). Pengembangan Teknologi Informasi Dan Komunikasi Dalam Sistem E-Health Alodokter.Com. Jurnal Sosioteknologi, 17.

Prasetya, E. B., \& Prakoso, B. (2020). Perancangan Sistem Pengelolaan Inventory dan Pelayanan Purna Jual (SIPENIPAL) Berbasis Web Menggunakan Metode FAST (Studi Kasus : PT. Anugrah Global Inti Persada). Tekinfo, 21(2), 32-39.

Pratama, N. A., \& Latipah. (2019). Perancangan Aplikasi Perencanaan Bahan Baku Menggunakan Metode Mrp ( Material Requirement Planning ) PADA PT. E-T-A INDONESIA. Insand Comtech, 4(2), 10-11.

Rahmadi, L., \& Yusmiarti, K. (2016). Perancangan Sistem Informasi Inventory Di Amik Lembah Dempo Pagaralam. SEMNASTEKNOMEDIA ONLINE, 4(1), 133-138. https://ojs.amikom.ac.id/index.php/semnast eknomedia/article/view/1246/0
Rishmaya, R. (2020). Sistem Informasi Pengendalian Bahan Baku Menggunakan Metode Material Requirement Planning Pada Pd. Samijaya Sukabumi Berbasis Web. Jurnal Sistem Komputer, 10(1), 17-23. https://doi.org/10.14710/jsk.v10i1.177

S., R. A., \& Shalahudin, M. (2018). Rekayasa Perangkat Lunak Terstruktur dan Berorientasi Objek (revisi). Informatika Bandung.

Susmita, A., \& Cahyana, B. J. (2018). Pemilihan Metode Permintaan Dan Perencanaan Kebutuhan Bahan Baku Dengan Metode Mrp Di PT. XYZ. Seminar Nasional Sains Dan Teknologi 2018 Fakultas Teknik Universitas Muhammadiyah Jakarta, 10. 
